\title{
RESISTANCE ASSESSMENT OF BEAM-TO-COLUMN JOINTS WITH DIFFERENT BLIND BOLT SYSTEMS
}

\author{
Anka Javora, Davor Skejić
}

Original scientific paper

Blind bolted connections enable simple joining of various beams to tubular columns. In the parametric analysis several different blind bolts systems were compared through the example of I-beam-to-hollow section column joint with extended endplate. 1155 combinations of parameters defining behaviour of considered joint type were analysed. The size of a bolthole or more precisely blind bolt geometry has major effect on joint resistance. The most common failure mode is bending of the column flange. In the cases where the thickness of the endplate is lower than or equal to the thickness of the column wall, endplate most frequently fails by bending. Obviously the use of an elliptical yield line mechanism and appreciation of the membrane action effect increase the joint resistance. It is suggested to investigate further the membrane action effect with the use of elliptical yield line mechanism especially in the region where the failure mode changes.

Keywords: blind bolts; beam-to-hollow section column joint; elliptical yield line pattern; membrane action; parametric analysis

\section{Procjena otpornosti priključaka nosač-stup s različitim sustavima slijepih vijaka}

Izvorni znastveni članak

Vijčani priključci izvedeni pomoću slijepih vijaka omogućavaju jednostavno priključivanje različitih profila nosača i cijevnih stupova. U parametarskoj analizi uspoređeno je nekoliko različitih sustava slijepih vijaka na primjeru priključaka I-nosač - cijevni stup s produljenom čelnom pločom. Analizirana je 1155 kombinacija parametara koji utječu na ponašanje razmatranog tipa priključka. Otpornost priključka uvelike ovisi o promjeru rupe odnosno preciznije o geometriji slijepog vijka. Najčešći način otkazivanja je otkazivanje pojasnice stupa savijanjem. Čelna ploča najčešće otkazuje savijanjem i to u slučajevima u kojima je debljina čelne ploče manja ili jednaka debljini pojasnice stupa. Očito je da primjena eliptičnog modela linija popuštanja i uvažavanje učinka membranskih sila povećava otpornost priključka. Predlaže se dodatno istražiti učinak membranskog djelovanja uz primjenu eliptičnih modela linija popuštanja naročito u području u kojemu nastupa promjena načina otkazivanja.

Ključne riječi: eliptični model; membransko djelovanje; parametarska analiza; priključak nosač - cijevni stup; slijepi vijci

\section{Introduction}

Welding was, for many years, the only way of connecting members to hollow section columns. This type of connection brings a number of problems such as providing the necessary conditions on the construction site, specialized manpower, access to joints and the complexity of the joint inspection. One particularly important problem while welding cold-formed hollow section is the occurrence of brittle fractures. Unlike hotrolled hollow sections which are more suitable for welding, cold-formed hollow sections have more reasonable prices. These are some of the reasons that inspired the idea of developing new ways of connecting through the usage of bolts with one sided tightening which are commonly referred to as blind bolts. The advantage of blind bolts is recognized in their specifically developed mechanisms which enable tightening from only one end of the connection. The development of blind bolts enables a wider application of various hollow section profiles because it is possible to connect hollow sections without welding on the construction site.

Due to their high torsional stiffness, high moment of inertia, and higher resistance to weight ratio when compared to open beams, hollow sections enable the usage of slender columns.

Having in mind both economical and structural aspects these columns are more suitable with regard to the usable floor area. Without doubt, one more argument for selecting hollow sections for columns is their aesthetics.

\section{Blind bolts systems}

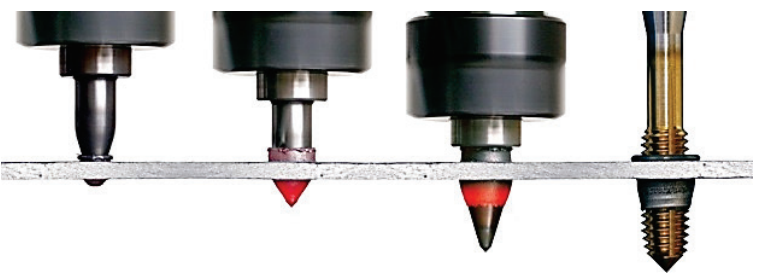

a) Flowdrill

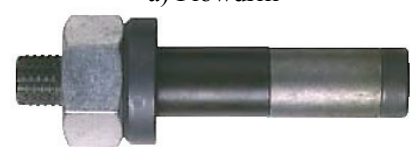

b) Huck Ultratwist

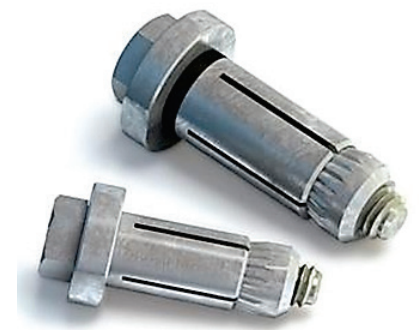

c) Hollo-bolt

d) Ajax ONESIDE

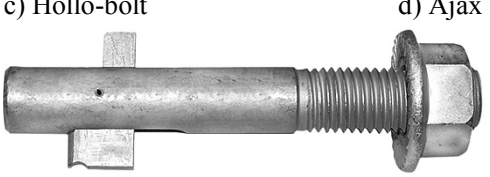

e) Blind bolt

Figure 1 Single-sided tightening systems

Nowadays there are several blind bolts systems, such as Huck High Strength Blind Bolt (HSBB) and Huck Blind Oversized Mechanically Locked Bolt (BOM), 
Lindapter Hollo-Bolt, Ajax ONESIDE and Blind bolt, Fig. 1. Although it is not a typical bolt, the Flowdrill system uses one sided tightening through a specifically developed drilling technique, Fig. 1a, and can be classified as blind bolt system.

Each of the aforementioned bolt systems has various bolt tightening techniques which have an impact on the behaviour of the bolt and the whole joint. The tightening techniques are described in detail in [1]. When observing the Flowdrill technique, the friction between the drill and the hollow section wall is used to drill a hole. As the special drill pushes into the material, some of the displaced material forms a collar around the external surface of the wall. The rest of the material forms a bushing in the internal surface of the wall. Huck Ultratwist is tightened by forming the bulb wrapped around the body of the sleeve, Hollo-bolt is tightened by expanding the legs of the sleeve; Ajax ONESIDE uses a collapsible stepped washer while Blind Bolt uses an anchor, Fig. 1.

\section{Failure modes of blind bolted joints 3.1 General}

The behaviour of bolted joints is extremely non-linear due to the mechanical properties of the materials, as well as the interaction between various parts of the joint itself. The complexity of the blind bolts structure contributes to that non-linearity. A well-known component method ensures a practical and simple way which can be used to describe basic mechanical characteristics of bolted joints. An appropriate bolted T-stub presents the idealisation of the joint tension zone behaviour where most of deformations are formed. Thus, the bending of the column face and the endplate can be described using an equivalent bolted T-stub model, [2].

Blind bolts are often used in joints where one of the elements is a hollow section. The hollow section wall ensures different boundary conditions with regard to the open section profiles. EN 1993-1-8, [3], does not specify the equations for design of beam-to-column joints where the column is hollow section and connecting is realized with blind bolts. Several authors have given suggestions based on their test results. For the bolted joints with endplate several different failure modes were found.

The failure modes that can occur in joints with extended endplate are: bolts in tension, bolts in shear, bolt bearing for plate and column face, column face punching shear, column face bending, column face bending and membrane action, column webs bearing and bending of the endplate. Flowdrill systems can also fail by thread stripping on the column flange, [4]. The behaviour of the joint is influenced by the dimensions of the endplate and the width of the column walls.

In cases where joints in bending have endplate width equal to the RHS column face width, the stiffness and column face bending resistance are increased, while the column yield lines are formed only at the joint tension zone. This only happens if crippling (local buckling) of the column walls close to the force introduction point is not governing failure mode. This particular dimension ratio (geometry) was chosen in the performed parametric analysis and thus the observed failure modes refer only to the joint tension zone and tensile action [5].

\subsection{Failure mode 1: blind bolts in tension}

Since blind bolts are construction products, their tension resistance is assessed through tests. There are two exceptions to this rule. The first one is the Flowdrill system which uses a standard bolt. The second one is the Blind bolt system for which characteristic tension resistance is calculated as proposed by EN 1993-1-8, [3]. Blind bolt system has bolt with reduced tensile stress area and according to manufacturer the reduction factor should be adopted as: $k_{2}=0,537$.

Blind bolt system bolts are produced in grade 10.9 only, but for the purposes of this analysis and result comparison, grade 8.8 was also assumed.

\subsection{Failure mode 2: column face thread stripping (Flowdrill system)}

The most common failure mode that occurs in the case of Flowdrill bolts is thread stripping of the column face which is accompanied with high column deformations, $[4,6]$. In the case of pure axial loading on the joints, the threads on the bolt and the threads on the flange remain in full contact, while the resistance of column face thread stripping $\left(F_{2, \mathrm{~F}}\right)$ for one bolt in tension is given by:

$F_{2, \mathrm{~F}}=0,6 \cdot f_{\mathrm{y}, \mathrm{c}} \cdot \pi \cdot d_{\mathrm{b}} \cdot\left(t_{\mathrm{c}, \mathrm{w}}+0,8\right)$

where is: $f_{\mathrm{y}, \mathrm{c}}$ - column yield strength, $d_{\mathrm{b}} \quad$ - bolt diameter, $t_{\mathrm{c}, \mathrm{w}}$ - column wall thickness.

In the tests done by British Steel [7], Park noticed that high deformations are formed on the edge of the hole in the case of column face in bending failure. Such deformities reduce the contact surface between the column flange and the bolt, Fig. 2 .

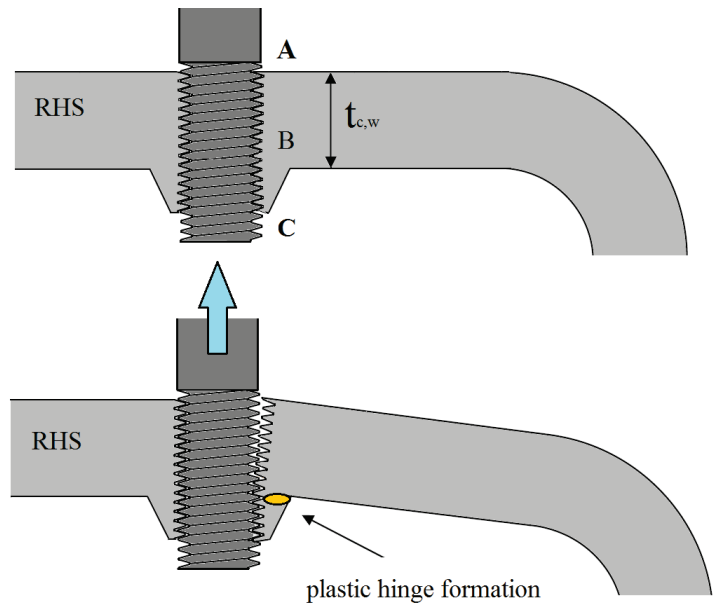

Figure 2 Bolt hole deformation and plastic hinge formation

Reduction in the contact surface between the column flange and the bolt is introduced with the linear reduction factor, as specified by Park according to the test results, [6]. The reduced thread stripping resistance for one bolt in tension is given by: 


$$
F_{2, \mathrm{~F}, \mathrm{red}}=R \cdot\left[0,6 \cdot f_{\mathrm{y}, \mathrm{c}} \cdot \pi \cdot d_{\mathrm{b}} \cdot\left(t_{\mathrm{c}, \mathrm{w}}+0,8\right)\right],
$$

where $R$ is reduction factor: $R=\tau \cdot t_{\mathrm{c}, \mathrm{w}} \leq 1,0$, and $\tau=$ 60.

\subsection{Failure mode 3: column face - punching shear of the bolt through the column face}

There are several suggestions for calculation of the punching shear resistance. All depend on the bolt system considered. According to [5] and [7], for Flowdrill systems the following expression is given for one bolt in tension:

$$
F_{3, \mathrm{~F}}=0,6 \cdot f_{\mathrm{y}, \mathrm{c}} \cdot \pi \cdot t_{\mathrm{c}, \mathrm{w}} \cdot\left(d_{\mathrm{b}}+t_{\mathrm{c}, \mathrm{w}}\right),
$$

In Flowdrill systems, shear is observed on the width determined by the bolt shank diameter and column flange thickness, while for other systems shear width is determined by their bolt diameter, $[5,8]$ :

$$
F_{3, \mathrm{HB}}=0,6 \cdot f_{\mathrm{y}, \mathrm{c}} \cdot \pi \cdot t_{\mathrm{c}, \mathrm{w}} \cdot d_{\mathrm{b}}
$$

Unlike other systems that use the bolt diameter, Huck system takes into consideration the primary bolt sleeve diameter, $d_{k}$, incurred by the deformation of the sleeve after bolt installation, [9]:

$$
F_{3, \mathrm{H}}=\frac{f_{\mathrm{y}, \mathrm{c}}}{\sqrt{3}} \cdot \pi \cdot t_{\mathrm{c}, \mathrm{w}} \cdot d_{\mathrm{k}}
$$

\subsection{Failure mode 4: column face in bending}

Calculation of the column flange deformation is based on the method of virtual work. Mourad, [9], suggested two ways of assessing the resistance; for linear and for circular yield line pattern, Fig. 3. The linear yield line pattern can be applied when the ratio between horizontal bolt distance and column's clear face width is $\mathrm{w} /\left(b-t_{\mathrm{c}, \mathrm{w}}\right) \geq 0,65$, while the circular yield line pattern can be applied when $\mathrm{w} /\left(b-t_{\mathrm{c}, \mathrm{w}}\right)<0,65$.

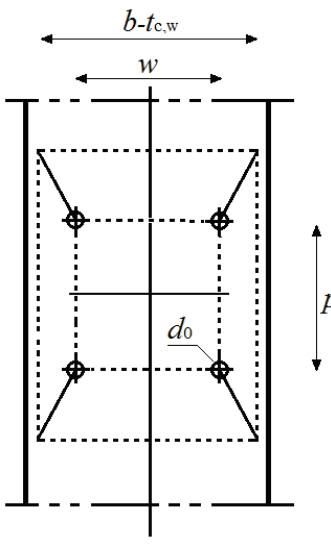

Linear yield line pattern Figure 3 Yield line patterns on the RHS column face, [9]

Park, [6], carried out a parametric analysis of the expression for column face bending resistance, along with finite element method analysis. Since plastic hinges are formed near the column side walls, Park analysed models with different widths of deformable clear column face. He compared the analytical model results with the test results, as well as the results from the finite element method. It has been shown that the width of RHS column clear face, $b-t_{c, w}$, adopted by Mourad, [9], thoroughly underestimated the resistance of the column. Thus, Park suggested the new width of RHS column clear face as $b-4 \cdot t_{\mathrm{c}, \mathrm{w}}$, Fig. 4 . He also suggested separate equations for the failure of bolt group and for bolt row failure based on four bolts.

A) Linear yield line pattern

- bolt group failure

$F_{4, \mathrm{P}, \mathrm{gl}}=4 M_{\mathrm{p}} \cdot\left[\frac{w+2 \cdot c-d_{\mathrm{b}}}{d_{1}}+\frac{p+2 \cdot d_{1}-0,5 \cdot n \cdot d_{\mathrm{b}}}{c}\right]$

- bolt row failure

$F_{4, \mathrm{P}, \mathrm{rl}}=4 M_{\mathrm{p}} \cdot\left[\frac{w+2 \cdot c-d_{\mathrm{b}}}{d_{1}}+\frac{2 \cdot d_{1}-0,5 \cdot d_{\mathrm{b}}}{c}\right] \cdot n$

where:

$M_{\mathrm{p}}=\frac{f_{\mathrm{y}, \mathrm{c}} \cdot t_{\mathrm{c}, \mathrm{w}}^{2}}{4}, c=\frac{b-4 t_{\mathrm{c}, \mathrm{w}}-w}{2}$,

$d_{1}=\sqrt{\frac{c}{2} \cdot\left(w+2 \cdot c-d_{\mathrm{b}}\right)}$

$w$ - horizontal bolt axis distance,

$p$ - vertical bolt axis distance,

$b$ - column width,

$n$ - number of bolt rows in tension.

B) Circular yield line pattern

- bolt group failure

$F_{4, \mathrm{P}, \mathrm{gk}}=4 M_{\mathrm{p}} \cdot\left[\frac{w+p-0,5 \cdot(n-1) \cdot d_{\mathrm{b}}}{c}+\pi-\frac{\pi \cdot d_{\mathrm{b}}}{4 \cdot c}\right]$

- bolt row failure

$F_{4, \mathrm{P}, \mathrm{rk}}=4 M_{\mathrm{p}} \cdot\left[\frac{w-0,5 \cdot d_{\mathrm{b}}}{c}+\pi-\frac{\pi \cdot d_{\mathrm{b}}}{4 \cdot c}\right] \cdot n$

C) Elliptical yield line pattern

- bolt group failure

$F_{4, \mathrm{P}, \mathrm{ge}}=M_{\mathrm{p}} \cdot\left[\frac{4 \cdot w-2 \cdot d_{\mathrm{b}}+2 \cdot \pi \cdot c-\pi \cdot d_{\mathrm{b}}}{d_{1}}\right]+$

$M_{\mathrm{p}} \cdot\left[\frac{4 \cdot p-2 \cdot(n-1) \cdot d_{\mathrm{b}}+2 \cdot \pi \cdot d_{1}}{c}\right]$,

- bolt row failure

$F_{4, \mathrm{P}, \mathrm{re}}=M_{\mathrm{p}} \cdot\left[\frac{4 \cdot w-2 \cdot d_{\mathrm{b}}+2 \cdot \pi \cdot c-\pi \cdot d_{\mathrm{b}}}{d_{1}}\right] \cdot n+$

$M_{\mathrm{p}} \cdot\left[\frac{2 \cdot \pi \cdot d_{1}}{c}\right] \cdot n$,

where:

$$
\begin{aligned}
& d_{1}=\sqrt{\frac{c}{2 \cdot \pi}+\left(4 \cdot w+2 \cdot d_{\mathrm{b}}+2 \cdot \pi \cdot c-\pi \cdot d_{\mathrm{b}}\right)}, \\
& F_{4, \mathrm{P}}=\min \left(F_{4, \mathrm{P}, \mathrm{i}}\right),
\end{aligned}
$$

The yield line patterns are shown in Fig. 4. The black line shows the elliptical yield line pattern while the red 
line shows the linear yield line pattern. The geometrical properties of $d_{1}$ and $c$ are equal when observing the circular yield line pattern.

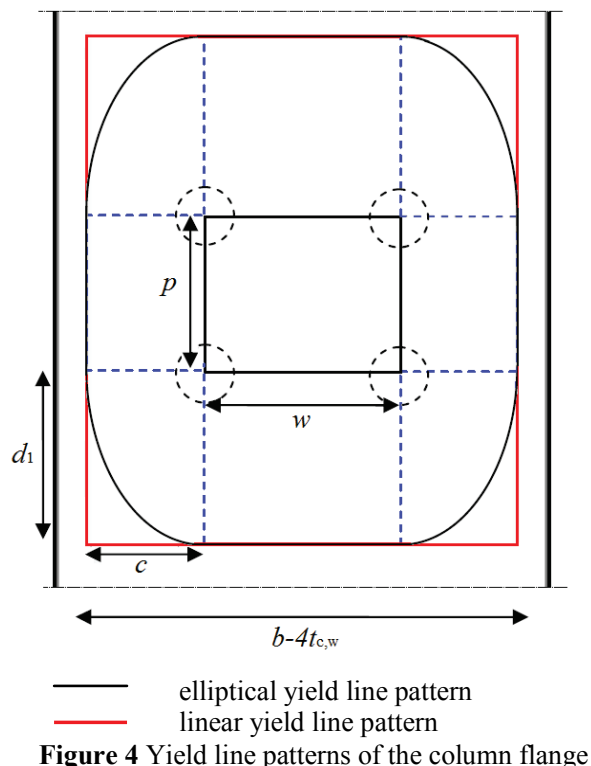

Generally, the elliptical yield line pattern gives lower resistance of column flange in bending. Circular and linear yield line patterns represent two marginal cases of the elliptical yield line pattern. The linear and elliptical yield lines give lower values in the case of high horizontal bolt distances - the same goes with the circular and elliptical yield lines in the case of the lower horizontal bolt distances. When observing the circular yield line pattern, the yield line parallel to the hollow section axis is equal to the yield line perpendicular to the hollow section axis.

The vertical bolt distance is another factor on which failure modes depend. Lower vertical bolt distances cause a bolt group failure while higher ones cause a bolt row failure.

Column web panels represent support to the column face in bending - this causes the column face to develop membrane action which in turn increases its resistance, Fig. 5.
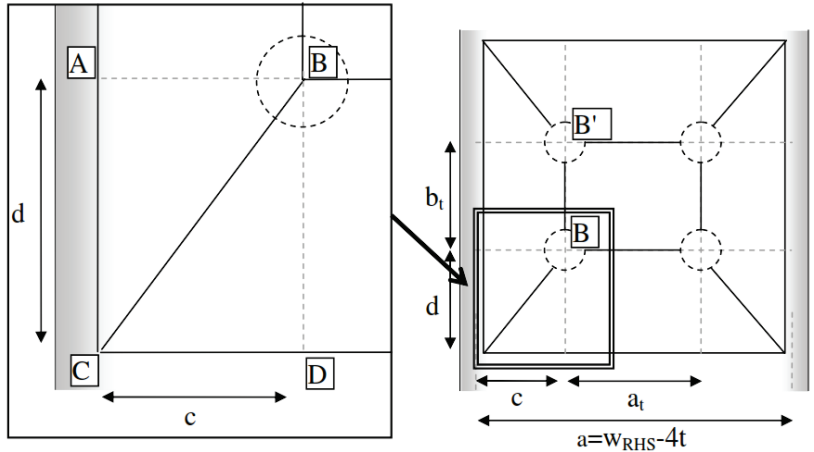

Figure 5 Column face membrane action, [6]

By using principle of virtual work, it is possible to relate the failure load of the column face to its deformation. For simplification, the linear (straight) line yield pattern is assumed, while the deflection profile is linear with the maximum deflection at the point of a bolthole (point B), and zero deflection at the corners of the yield lines (point C), Fig. 5. The membrane action resistance is derived for:

- bolt group failure

$$
\begin{aligned}
F_{4, \mathrm{~m}, \mathrm{~g}}= & 8 \cdot M_{\mathrm{p}} \cdot \delta_{\mathrm{b}} \cdot\left[\frac{w-d_{\mathrm{b}}}{d_{1}}+\frac{p-(n-1) \cdot d_{\mathrm{b}}}{c}\right]+ \\
& 8 \cdot M_{\mathrm{p}} \cdot \delta_{\mathrm{b}} \cdot\left[\frac{2}{3}-\frac{d_{\mathrm{b}}^{3}}{12 \cdot L_{\mathrm{d}}^{3}}\right],
\end{aligned}
$$

- bolt row failure

$F_{4, \mathrm{~m}, r}=8 \cdot M_{\mathrm{p}} \cdot \delta_{\mathrm{b}} \cdot\left[\frac{w-d_{\mathrm{b}}}{d_{1}}+\frac{2}{3}-\frac{d_{\mathrm{b}}^{3}}{12 \cdot L_{\mathrm{d}}^{3}}\right] \cdot n$,

where:

$L_{\mathrm{d}}=\sqrt{c^{2}+d_{1}^{2}}, \quad \delta_{\mathrm{b}}=\sqrt{c^{2}-c^{2}}, \quad c^{\prime}=c \cdot\left(1+\varepsilon_{\mathrm{u}}\right)$.

Park, [6], suggests that these equations should be applied for calculation of the concrete-filled RHS where the lowest value between the two failure modes is governed:

$F_{4, \mathrm{~m}, \mathrm{uk}, \mathrm{CFT}}=\min \left(F_{\mathrm{m}, \mathrm{g}} ; F_{\mathrm{m}, \mathrm{r}}\right)$,

For column web panels which do not provide a full restraint, the failure mechanism of column face is a combination of bending caused by yielding and membrane action. It is given by:

$$
F_{4, \mathrm{~m}, \mathrm{uk}, \mathrm{SHS}}=0,5 \cdot F_{4, \mathrm{P}, \mathrm{e}}+0,5 \cdot \min \left(F_{\mathrm{m}, \mathrm{g}} ; F_{\mathrm{m}, \mathrm{r}}\right),
$$

\subsection{Failure mode 5: column web crippling}

The column web crippling resistance is not dependent on the bolts. It can be assessed according to [7]:

$$
F_{5, \mathrm{Y}}=2 \cdot\left[f_{\mathrm{u}, \mathrm{c}} \cdot t_{\mathrm{c}, \mathrm{w}} \cdot\left(t_{\mathrm{b}, \mathrm{f}}+2 \cdot t_{\mathrm{p}}+3 \cdot t_{\mathrm{c}, \mathrm{w}}\right)\right],
$$

or according to [5]:

$$
F_{5, \mathrm{~K}}=2 \cdot\left[f_{\mathrm{y}, \mathrm{c}} \cdot t_{\mathrm{c}, \mathrm{w}} \cdot\left(t_{\mathrm{b}, \mathrm{f}}+2 \cdot t_{\mathrm{p}}+5 \cdot t_{\mathrm{c}, \mathrm{w}}\right)\right] \text {, }
$$

\section{Parametric analysis of blind bolted joints 4.1 Input parameters}
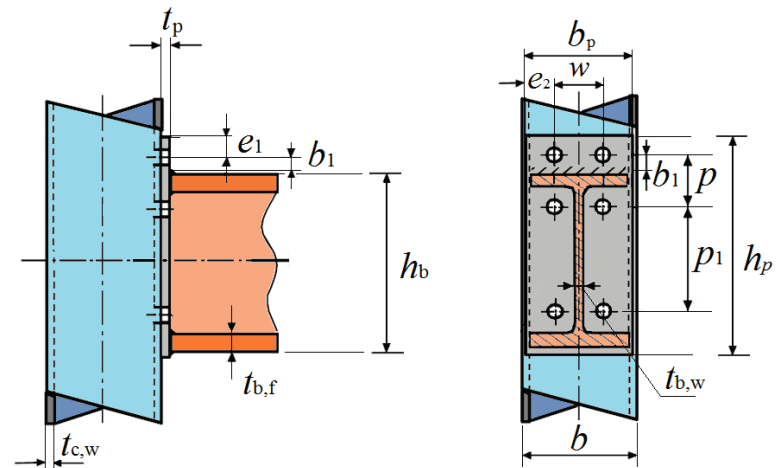

Figure 6 Analysed beam-to-column joint with an extended endplate and various blind bolt systems

Analysed beam-to-column joint with an extended endplate and various blind bolt systems is shown in Fig. 6. Column was always hot-rolled square hollow section 
(SHS) $200 \times 200$ and the endplate steel quality was S 235 $\left(f_{\mathrm{y}, \mathrm{p}}=235 \mathrm{MPa}\right)$.

The influence of joint parts geometrical and mechanical properties on a joint resistance is assessed through the parametric analysis in which parameters listed in Tab. 1 were varied. 1155 parameter combinations were analysed. The weakest component is governed for determining joint bending resistance. It also represents the joint's failure mode.

Table 1 Variation of parameters in the analysis

\begin{tabular}{|c|c|}
\hline $\begin{array}{c}\text { Column yield strength } \\
f_{\mathrm{y}, \mathrm{c}}(\mathrm{MPa})\end{array}$ & $235 ; 275 ; 355$ \\
\hline $\begin{array}{c}\text { Endplate yield strength } \\
f_{\mathrm{y}, \mathrm{p}}(\mathrm{MPa})\end{array}$ & 235 \\
\hline Bolt size & $\mathrm{M} 12 ; \mathrm{M} 16 ; \mathrm{M} 20 ; \mathrm{M} 24$ \\
\hline Bolt grade & 8.8 and 10.9 \\
\hline $\begin{array}{c}\text { Column wall thickness } \\
t_{\mathrm{c}, \mathrm{w}}(\mathrm{mm})\end{array}$ & $5 ; 6,3 ; 8 ; 10 ; 12,5 ; 14,2 ; 16$ \\
\hline $\begin{array}{c}\text { Endplate thickness } \\
t_{\mathrm{p}}(\mathrm{mm})\end{array}$ & $6 ; 12 ; 16$ \\
$w$ (mm) & $50 ; 60 ; 70 ; 80 ; 90 ; 100 ; 110 ; 120 ;$ \\
$\begin{array}{c}\text { Horizontal bolt distance } \\
w\end{array}$ & $50 ; 60 ; 70 ; 80 ; 90 ; 100 ; 110 ; 120 ;$ \\
& 130 \\
\hline $\begin{array}{c}\text { Vertical bolt distance } \\
(\mathrm{mm})\end{array}$ & \\
\hline
\end{tabular}

\subsection{The frequency of failure modes}

The frequency of particular failure mode from the total number of analysed failure modes by blind bolt system is shown in Fig. 7, while the total frequency which is not dependent on the type of bolt used is shown in the diagram legend.

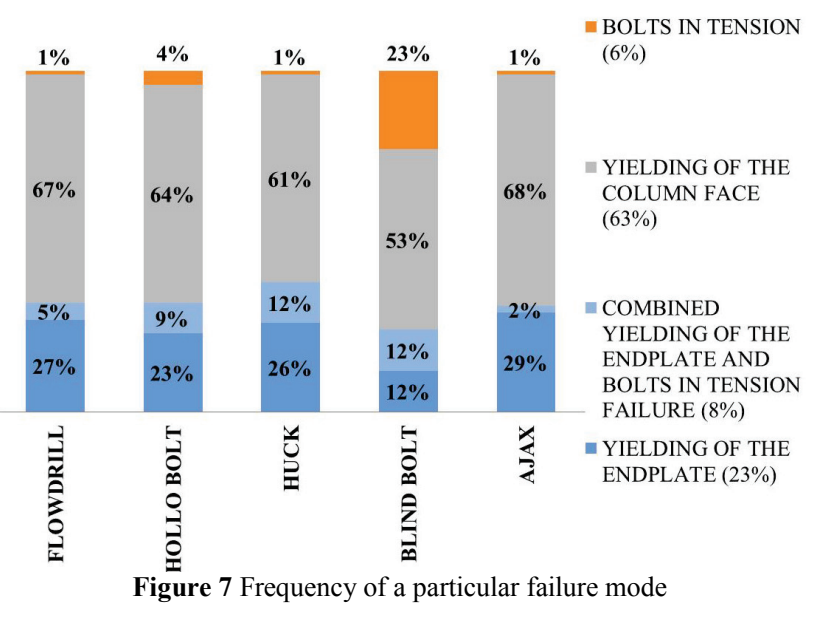

\subsection{Influence of bolt properties}

Hollo-Bolt, Huck, and Ajax ONESIDE systems are complex systems which are comprised of a bolt shank and a bolt sleeve around the shank. Their tensile strength is taken from the manufacturer's certificate. On the other hand, Flowdrill systems use a standard bolt and thus their tensile strength is equal to the tensile strength of a standard bolt. The surface of the bolt shank in Blind bolt systems, $A_{\text {pin }}$, is reduced and can be found in the manufacturer's catalogue. Blind bolt system bolts are produced in grade 10.9 only, but grade 8.8 was also assumed for the purposes of this analysis.
There were eight failures of bolt in tension with Ajax ONESIDE, 12 with Huck bolts, 14 with Flowdrill system, 32 with Hollo-Bolt system and 268 with Blind bolt system, Fig. 7. For all bolt systems only four combinations of parameters cause bolt in tension failure. The parameters were as follows: bolt axis distance $(p=50$ $\mathrm{mm}, w=50 \mathrm{~mm})$, maximal endplate thickness $\left(t_{\mathrm{p}}=16\right.$ $\mathrm{mm}), \mathrm{M} 12$ bolt, maximal column thicknesses $\left(t_{\mathrm{c}, \mathrm{w}}: 14,2\right.$ and $16 \mathrm{~mm}$ ).

Hollo-Bolt system bolts failed only in two cases while using M16 bolts with high thicknesses of endplate and column flange. Blind bolt system failed 268 times, regardless of the size of the bolt used.

Tab. 2 shows the minimum parameter values that can cause bolt in tension failure for a particular joint. The first number represents the minimum endplate thickness (min $\left.t_{\mathrm{p}}\right)$, the second number represents the minimum column wall thickness (min $\left.t_{\mathrm{c}, \mathrm{w}}\right)$, while the third number represents the minimum column material yield stress (min $\left.f_{\mathrm{y}, \mathrm{c}}\right)$ at which the bolt in tension failure occurred. The endplate yield stress is unchanged (235 MPa), while the bolt grade is 8.8 . Only once M24 bolt failed. This was within Blind bolt system while using grade 8.8 , although it is largely non-existent in practice since Blind bolts system bolts are produce in grade 10.9 only. Nevertheless, generally, Blind bolt system provides the lowest tensile strength because of the reduced bolt shank area, $A_{\text {pin }}$.

Table 2 Minimal parameter values for bolt in tension failure

\begin{tabular}{|c|c|c|c|c|c|}
\hline \multicolumn{6}{|c|}{$\left(\min t_{\mathrm{p}} ; \min t_{\mathrm{c}, \mathrm{w}}\right)(\mathrm{mm}) / \min f_{\mathrm{y}, \mathrm{c}}\left(\mathrm{N} / \mathrm{mm}^{2}\right)$} \\
\hline Bolt & Flowdrill & Hollo bolt & Huck & Blind bolt & $\begin{array}{c}\text { Ajax } \\
\text { ONESIDE }\end{array}$ \\
\hline M12 & $\begin{array}{c}12,0 ; 14,2 \\
/ 355\end{array}$ & $\begin{array}{c}12,0 ; 12,5 \\
/ 355\end{array}$ & $\begin{array}{c}16,0 ; 12,5 \\
/ 355\end{array}$ & $\begin{array}{c}6,0 ; 6,3 \\
/ 275\end{array}$ & $\begin{array}{c}12,0 ; 14,2 \\
/ 355\end{array}$ \\
\hline M16 & - & $\begin{array}{c}12,0 ; 16,0 \\
/ 355\end{array}$ & - & $\begin{array}{c}6,0 ; 12,5 \\
/ 275\end{array}$ & - \\
\hline M20 & - & - & - & $\begin{array}{c}12,0 ; 14,2 \\
/ 355\end{array}$ & - \\
\hline M24 & - & - & - & $\begin{array}{c}16,0 ; 16,0 \\
/ 355\end{array}$ & - \\
\hline
\end{tabular}

\subsection{Influence of endplate}

The endplate failure occurred 160 times in all blind bolt systems with the same combination of parameters. Depending on blind bolt system, failure occurred 272 times with the Blind bolt system, 290 times with the Hollo-Bolt system, 357 for Ajax ONESIDE system, 362 times with the Flowdrill system and 440 times with the Huck system. This finding proves that endplate failure is not a common failure mode. Endplate failure most commonly occurred with Huck systems (combined endplate yielding and bolt in tension failure, as well as endplate yielding make $38 \%$ of failure modes), while the Blind bolt system showed the least amount of endplate failure modes (24\%), Fig. 7.

Endplate failure can occur in two ways. The first one is the pure yielding of the endplate where full plastic moment resistance is reached and yield mechanism on the endplate is formed, Fig. 8a. The second one is a combined failure mode where both the full plastic moment resistance and the bolt tension resistance have simultaneously been achieved, Fig $8 \mathrm{~b}$.

The first failure mode depends on the geometrical properties of the endplate $\left(b_{\mathrm{p}}, t_{\mathrm{p}}\right)$, distance between one 
bolt row and centre of the beam flange fillet weld $b_{1}$, diameter of the bolthole $d_{0}$, and endplate yield strength $f_{\mathrm{y}, \mathrm{p}}$. The combined failure mode is dependent on the bolt tension resistance $F_{\mathrm{t}}$, vertical distance between the bolthole centreline and the endplate edge, $e_{1}$, and the distance between the bolthole centreline and centre of the beam flange fillet weld, $b_{1}$.

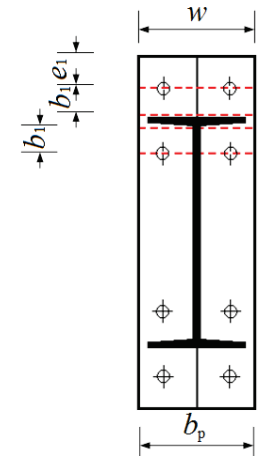

a) pure yielding of the endplate b) combined failure mode Figure 8 Endplate yield lines

In the performed analyses the thickness ratio between endplate and column flange $\left(t_{\mathrm{p}} / t_{\mathrm{c}, \mathrm{w}}\right)$ varied between 0,38 3,2. In Tab. 3 one can observe an example which shows the influence of endplate thickness on the behaviour of the joint for three different cases where endplate thickness is 6,12 and $16 \mathrm{~mm}$. In this example, the column flange varies in thickness according to the following parameters: $5,6,3,8,10,12,5,14,2$ and $16 \mathrm{~mm}$. The values of all the other parameters are fixed: $f_{\mathrm{y}, \mathrm{c}}=275 \mathrm{MPa}, p=100 \mathrm{~mm}, w$ $=100 \mathrm{~mm}$, and bolt M20, grade 10.9 .

Yielding of the $6 \mathrm{~mm}$ thick endplate occurs when $t_{\mathrm{p}} / t_{\mathrm{c}, \mathrm{w}}<0,75$. When endplate thickness is equal to $12 \mathrm{~mm}$, yielding of the endplate occurs when $t_{\mathrm{p}} / t_{\mathrm{c}, \mathrm{w}}<0,85$; Blind bolt system being the only exception. Increasing the endplate thickness to $16 \mathrm{~mm}$ causes yielding of the endplate in the case of Hollo-Bolt systems when $t_{\mathrm{p}} / t_{\mathrm{c}, \mathrm{w}}<$ 1,0 . In all other cases, column face yielding or bolt in tension failure occurs. It is important to note that in the case of Hollo-Bolt system, one should follow the manufacturer's guidelines and avoid using M16 and M20 bolts when endplate thickness is smaller than $8 \mathrm{~mm}$, [11]. Thus, for the purpose of results comparison, Hollo-Bolt system was considered in this analysis when endplate thickness was equal to $6 \mathrm{~mm}$. Kurobane et al., [5], suggests that joints whose endplate thickness is lower than column flange thickness should be checked for yielding of the column face and combined failure mode.

When observing all parameter combinations where $t_{\mathrm{p}} / t_{\mathrm{c}, \mathrm{w}}>>1,0$, the column flange has the lowest bending resistance. Huck M12 bolt with reduced tension resistance is the only exception. Endplate fails in the range $t_{\mathrm{p}} / t_{\mathrm{c}, \mathrm{w}}=$ $0,38 \div 1,0$.

In this analysis, the lowest bending resistance value is the one given by Kurobane et al., [5], which assumes a linear yield line pattern of the column flange and the width of RHS clear face $b-t_{\mathrm{c}, \mathrm{w}}$. If this equation is replaced with the one suggested by Park [6], which assumes an elliptical yield line pattern and the width of RHS clear face $b-4 \cdot t_{\mathrm{c}, \mathrm{w}}$, the bending resistance of the column flange would increase. Furthermore, the endplate would then have the lowest bending resistance. This would imply further checks for bending of the endplate when $t_{\mathrm{p}} / t_{\mathrm{c}, \mathrm{w}_{\mathrm{w}}} \leq$ 1,0 .

It is interesting to note the example shown in Table 3 where failure of the bolt in tension occurs with the Blind bolt system when column thicknesses are $t_{\mathrm{c}, \mathrm{w}}=16 \mathrm{~mm}$ and $14,2 \mathrm{~mm}$, and endplate thickness is $t_{\mathrm{p}}=16 \mathrm{~mm}$. This is due to the low tensile bolt resistance of this system. The tensile resistance of the Blind bolt system bolt is equal to $289,1 \mathrm{kN}$ and it is the primary cause of failure up to the moment when endplate and column wall thickness ratio $\left(t_{\mathrm{p}} / t_{\mathrm{c}, \mathrm{w}}\right)$ becomes higher than 1,13 . At this ratio, there is a small difference between the bolts' tensile resistance $(289,1 \mathrm{kN})$ and endplate bending resistance with the combined tension bolt failure $(294,0 \mathrm{kN})$. In the case of Hollo-Bolt system, failure of the endplate occurs when endplate and column wall thicknesses are equal to $16 \mathrm{~mm}$. In all other combinations, failure of the column flange occurs.

Table 3 Failure modes with regard to the column wall to endplate thickness ratio $\left(t_{\mathrm{p}} / t_{\mathrm{c}, \mathrm{w}}\right)$ for $p=100 \mathrm{~mm}, w=100 \mathrm{~mm}, f_{\mathrm{y}, \mathrm{c}}=275 \mathrm{MPa}$, bolt

\begin{tabular}{|c|c|c|c|c|c|c|c|}
\hline \multirow[b]{2}{*}{$\begin{array}{c}t_{\mathrm{p}} \\
/ \mathrm{mm}\end{array}$} & \multirow[b]{2}{*}{$\begin{array}{c}t_{\mathrm{c}, \mathrm{w}} \\
/ \mathrm{mm}\end{array}$} & \multirow[b]{2}{*}{$t_{\mathrm{p}} / t_{\mathrm{c}, \mathrm{w}}$} & \multicolumn{5}{|c|}{ Failure mode } \\
\hline & & & Flowdrill & $\begin{array}{c}\text { Hollo } \\
\text { bolt }\end{array}$ & Huck & $\begin{array}{c}\text { Blind } \\
\text { bolt }\end{array}$ & $\begin{array}{c}\text { Ajax } \\
\text { ONESIDE }\end{array}$ \\
\hline \multirow{7}{*}{6} & 5 & 1,20 & $\mathrm{R} 4$ & R4 & R4 & R4 & R4 \\
\hline & 6,3 & 0,95 & R4 & R4 & $\mathrm{R} 4$ & R4 & R4 \\
\hline & 8 & 0,75 & R7 & R7 & R7 & R7 & R7 \\
\hline & 10 & 0,60 & R7 & R7 & R7 & R7 & R7 \\
\hline & 12,5 & 0,48 & R7 & R7 & R7 & R7 & R7 \\
\hline & 14,2 & 0,42 & R7 & R7 & R7 & R7 & R7 \\
\hline & 16 & 0,38 & R7 & R7 & R7 & R7 & R7 \\
\hline \multirow{7}{*}{12} & 5 & 2,40 & $\mathrm{R} 4$ & $\mathrm{R} 4$ & $\mathrm{R} 4$ & $\mathrm{R} 4$ & $\mathrm{R} 4$ \\
\hline & 6,3 & 1,90 & R4 & R4 & $\mathrm{R} 4$ & R4 & R4 \\
\hline & 8 & 1,50 & R4 & R4 & $\mathrm{R} 4$ & $\mathrm{R} 4$ & R4 \\
\hline & 10 & 1,20 & R4 & R4 & $\mathrm{R} 4$ & R4 & R4 \\
\hline & 12,5 & 0,96 & R4 & $\mathrm{R} 4$ & $\mathrm{R} 4$ & R7 & $\mathrm{R} 4$ \\
\hline & 14,2 & 0,85 & R7 & R7 & R7 & R7 & R7 \\
\hline & 16 & 0,75 & R7 & R7 & R7 & R7 & R7 \\
\hline \multirow{7}{*}{16} & 5 & 3,20 & R4 & R4 & R4 & R4 & R4 \\
\hline & 6,3 & 2,54 & R4 & R4 & $\mathrm{R} 4$ & R4 & R4 \\
\hline & 8 & 2,00 & R4 & R4 & R4 & R4 & R4 \\
\hline & 10 & 1,60 & R4 & R4 & $\mathrm{R} 4$ & R4 & R4 \\
\hline & 12,5 & 1,28 & R4 & R4 & R4 & R4 & R4 \\
\hline & 14,2 & 1,13 & R4 & R4 & R4 & R1 & R4 \\
\hline & 16 & 1,00 & R4 & R7 & $\mathrm{R} 4$ & R1 & R4 \\
\hline
\end{tabular}

Legend: $\mathrm{R} 1$ bolt in tension, $\mathrm{R} 4$ bending failure of the column flange, R7 bending of the endplate, R7 combined failure mode.

Fig. 9 shows dependency of the joint components resistances, $F_{i}$, on the ratio $t_{\mathrm{p}} / t_{\mathrm{c}, \mathrm{w}}$. Three groups of diagrams derived from the combination of parameters shown in Tab. 2 are shown in Fig. 9. Each diagram represents a particular case of endplate thickness where, dependent on the continuous reduction of column wall thickness, joint resistances are given.

When $t_{\mathrm{p}} / t_{\mathrm{c}, \mathrm{w}}=1,0$, the component with the lowest bending resistance changes. Thus, the part of the diagram lines referring to $t_{\mathrm{p}} / t_{\mathrm{c}, \mathrm{w}}<1,0$ usually represents the face bending resistance of the endplate, while the diagram lines referring to $t_{\mathrm{p}} / t_{\mathrm{c}, \mathrm{w}}>1,0$ represent the face bending resistance of the column flange. The change of the component with the lowest bending resistance can be seen as change of the diagram line direction.

Each line on a particular diagram represents the behaviour of a joint with a particular bolt system. 
The first diagram group in Fig. 9 represents endplate thickness equal to $6 \mathrm{~mm}$ and shows pure yielding of the column flange or the endplate. Since this group shows failure modes which are dependent only on geometrical and mechanical properties of the endplate and the column flange, failure occurs by yielding of the endplate when $t_{\mathrm{p}} / t_{\mathrm{c}, \mathrm{w}}<1,0$ and therefore joint resistance does not change in this range. The resistance of the endplate is dependent on the bolthole size. Thus, when using the Hollo-Bolt system with the largest bolthole size, the endplate has the lowest bending resistance and it is govern component. Since the bolthole diameter is equal in both Huck and Blind bolt systems, endplate's resistance lines are overlapped in the diagram.
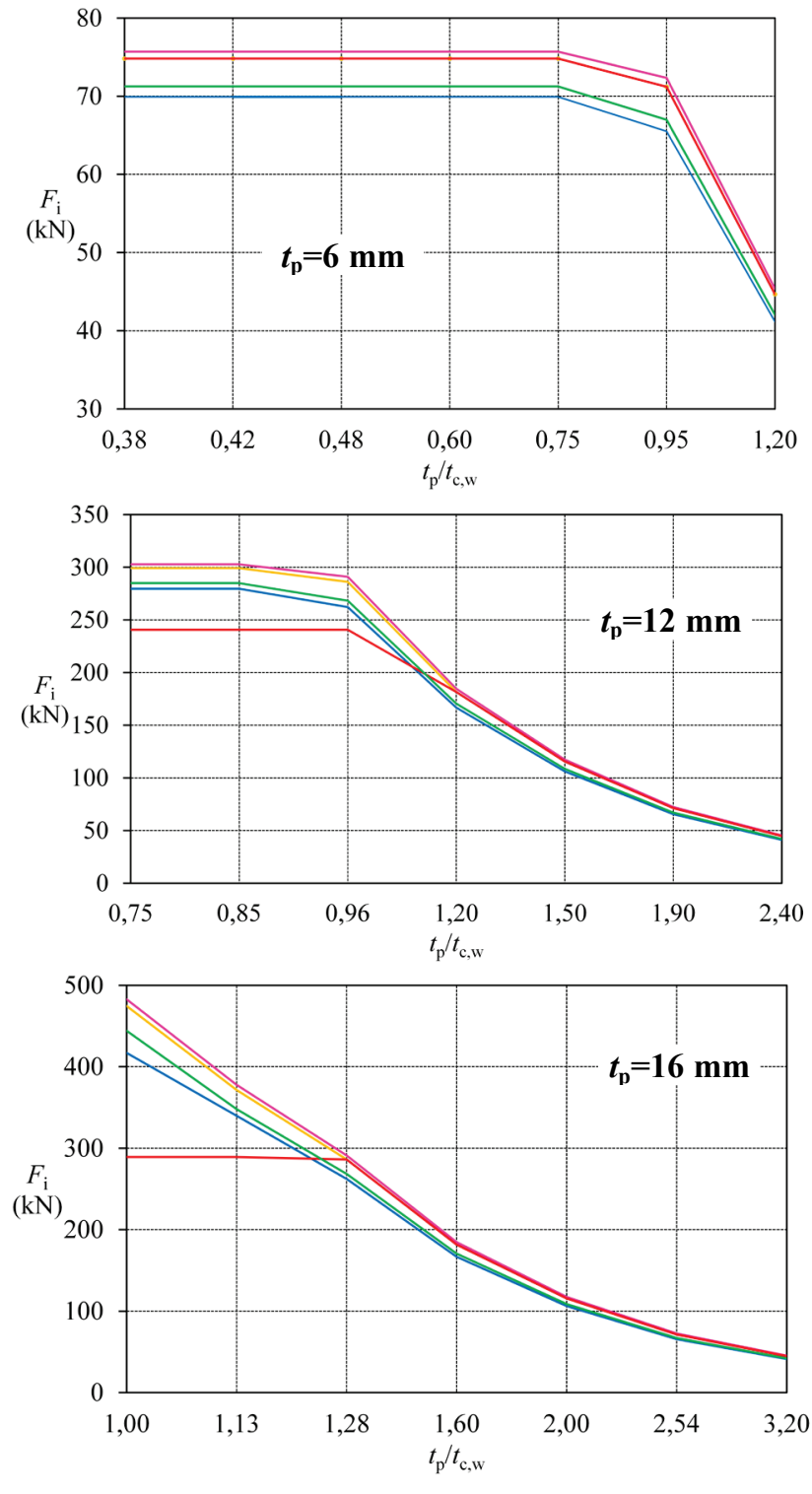

ajax Blind bolt Huck Hollo Bolt $\quad$ Flowdrill Figure 9 Influence of the column flange geometrical properties on bending resistance of govern joint components

A combined failure mode of the endplate and bolts occurs only with the Blind bolt system when endplate thickness is equal to $12 \mathrm{~mm}$. Within the range $t_{\mathrm{p}} / t_{\mathrm{c}, \mathrm{w}}=$ $0,75 \div 0,96$ endplate also yields in a combined mode when Blind bolt system is applied. In this particular case, its resistance is unchanged.
Column face in bending becomes govern when $t_{\mathrm{p}} / t_{\mathrm{c}, \mathrm{w}}$ $>0,96$. Reducing the column flange thickness also reduces its bending resistance. For other bolt systems pure yielding of the endplate occurs when $t_{\mathrm{p}} / t_{\mathrm{c}, \mathrm{w}}<0,85$ and then diagram lines show endplate resistance. Lines represent column flange resistance when $t_{\mathrm{p}} / t_{\mathrm{c}, \mathrm{w}}>0,85$. If Park's equation for elliptical yield line pattern was used with bolt group failure, part of the line $t_{\mathrm{p}} / t_{\mathrm{c}, \mathrm{w}}<0,96$ would remain the same since the endplate would be govern in the range $0,85<t_{\mathrm{p}} / t_{\mathrm{c}, \mathrm{w}}<0,9$ also.

The third group of graphs represents joints with endplate thickness equal to $16 \mathrm{~mm}$. The horizontal part of the red line represents the tensile resistance of the Blind bolt system bolt, i.e. failure labelled as R1 in Table 3 . There is a change of failure mode at $t_{\mathrm{p}} / t_{\mathrm{c}, \mathrm{w}}=1,28$. Part of the blue line up to 1,13 represents combined resistance of endplate and bolt in Hollo-Bolt system while the remaining part of the diagram represents the column face bending resistance. Due to the largest size of the bolthole among all the systems, Hollo-Bolt system again shows the lowest column face bending resistance.

Combined bolt and endplate failure occurred 18 times in all systems $(1,6 \%$ of the analysed parameter combinations). Blind bolt system was the exception since it only exhibited bolt in tension failure. In those cases when Blind bolt system fails through combined bolt and endplate failure, other systems fail due to plastic hinge formations on the endplate, that is, pure endplate yielding (bending). Combined bolt and endplate failure occurs when smallest bolts are used (M12) and when $t_{\mathrm{p}} / t_{\mathrm{c}, \mathrm{w}}=$ $0,75 \div 1,2$. Combined failure mode occurs with Ajax system when $t_{\mathrm{p}} / t_{\mathrm{c}, \mathrm{w}}<1,2$, Flowdrill, Hollo-Bolt and Blind bolt system when $t_{\mathrm{p}} / t_{\mathrm{c}, \mathrm{w}}<1,5$, and Huck system when $t_{\mathrm{p}} / t_{\mathrm{c}, \mathrm{w}}<2,4$.

Furthermore, the parametric analyses have included the range of endplate thickness and vertical bolt distance ratio as given by $t_{\mathrm{p}} / p=0,06 \div 0,32$. It has shown that the endplate failure occurs when the observed ratio is between $0,06 \div 0,15$ for Flowdrill, Hollo-Bolt and Ajax systems while for Huck and Blind bolt systems this ratio is ranged up to 0,24 .

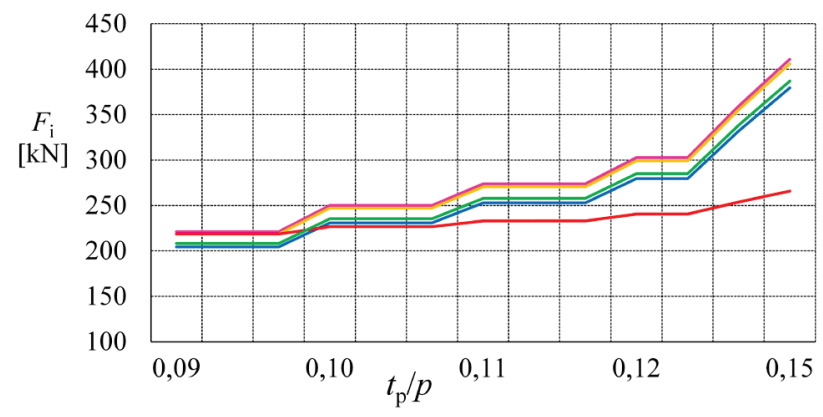

$\square$ Ajax $\square$ Blind bolt $\square$ Huck $\quad$ Hollo Bolt $\square$ Flowdrill

Figure 10 Influence of vertical bolthole distance, $p$, on the endplate bending resistance, $F_{i}$

The influence of the vertical bolthole distance $p$ on the endplate bending resistance, $F_{i}$, is shown in Fig. 10. The figure shows the change in bolt axes distance within the range where $p=80 \div 130 \mathrm{~mm}$ in those cases in which failure of the endplate occurred. The fixed values are endplate thickness, $t_{\mathrm{p}}=12 \mathrm{~mm}$, bolt grade 10.9, M20 bolts, column yield strength $f_{\mathrm{y}, \mathrm{c}}=275 \mathrm{MPa}$ and horizontal 
bolt axis distance $w=100 \mathrm{~mm}$. It can be noted that reduction of the vertical bolt distance will increase the endplate bending resistance.

The influence of vertical bolt distance, $p$, for all of the analysed parameter combinations is shown in Fig. 11. Each graph wave represents a particular vertical bolt distance value, $p$, which is fixed. Parts of the graph parallel to the horizontal axis represent the endplate bending resistance, i.e. in those parts the graphs show joints that fail due to the bending of endplate. In other parts, the graphs show failures due to the bending of column face. Flowdrill and Huck systems show the highest, while Blind bolt system show the lowest endplate bending resistance.

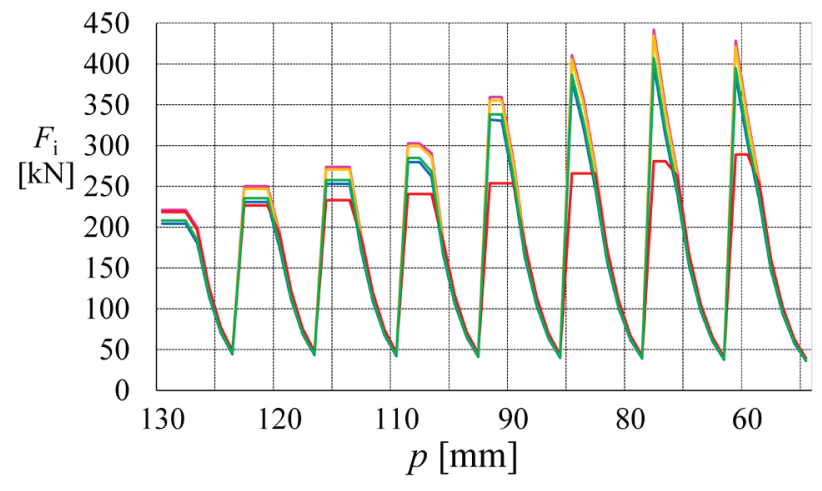

Ajax $\square$ Blind bolt $\square$ Huck $\quad$ Hollo Bolt $\square$ Flowdrill

Figure 11 Influence of vertical bolt distance, $p$, on the change of govern component resistance, $F_{i}$, depending on the Blind bolt system applied

It should be noted that the general assumption in considered analyses was that there are no limitations for bolt installation. That was assumed in order to conduct a detailed analysis which would reveal influence of the bolt distance on the joint behaviour.

\subsection{Influence of column flange}

Taking into account the number of joint failures due to combined failure of bolt in tension and endplate in bending, it can be concluded that column flange in bending is the most frequent failure mode of this joint type. Yielding of the column flange occurred in $63 \%$ of the observed parameter combinations.

Column flange behaviour is conditioned by its thickness $\left(t_{\mathrm{c}, \mathrm{w}}\right)$, ratios between the RHS column clear face and vertical and horizontal bolthole distance $\left(\left(b-4 t_{\mathrm{c}, \mathrm{w}}\right) / p\right.$; $\left.\left(b-4 t_{\mathrm{c}, \mathrm{w}}\right) / w\right)$, column yield strength $\left(f_{\mathrm{y}, \mathrm{c}}\right)$, as well as the bolt type used and its diameter.

As expected, increasing the column flange thickness increases its bending resistance. Fig. 12 shows changes in column bending resistance for various systems and the analysed joint where: column yield strength $f_{\mathrm{y}, \mathrm{c}}=275$ $\mathrm{MPa}$, endplate thickness $t_{\mathrm{p}}=12 \mathrm{~mm}, \mathrm{M} 20$ bolts, bolt grade 10.9 , vertical bolt distance $p=70 \mathrm{~mm}$, horizontal bolt distance $w=70 \mathrm{~mm}$.

Flowdrill system shows the highest column bending resistance, followed by Huck and Blind bolt systems. Hollo-Bolt system shows the lowest column bending resistance. The differences in column bending resistance with various systems are due to different bolthole size for the same nominal bolt diameter. For example, M20 bolts in Holl-Bolt system have a bolthole diameter equal to 33 mm, Ajax ONESIDE $30 \mathrm{~mm}$, Huck and Blind bolt 22 $\mathrm{mm}$. Flowdrill system has also a bolthole diameter equal to $22 \mathrm{~mm}$, but it is noted that Flowdrill system should be calculated for a bolthole whose size is equal to the bolt diameter $(20 \mathrm{~mm})$. The influence of the bolt system on column bending resistance can be seen on the example shown in Fig. 13 and Fig. 14.

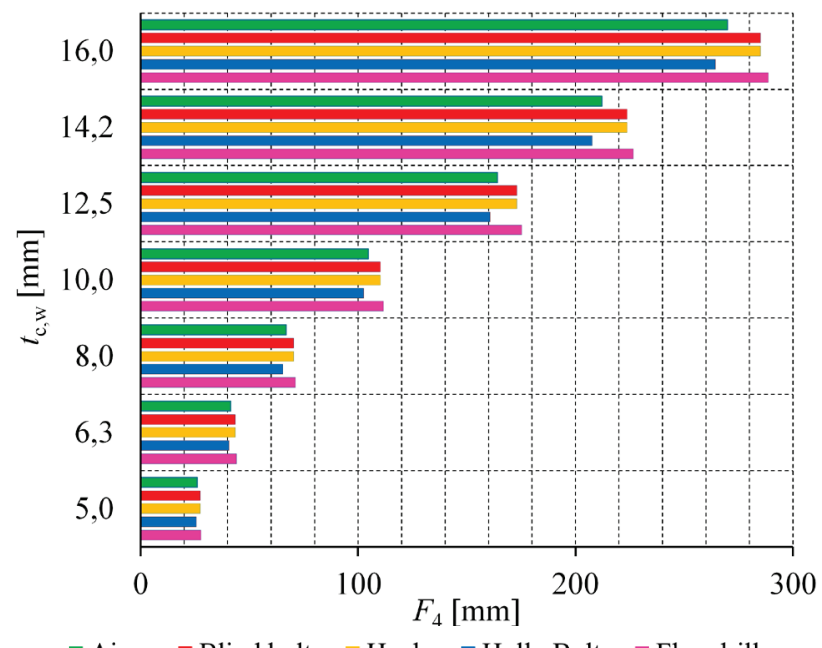

Ajax $\quad$ Blind bolt $\quad$ Huck $\quad$ Hollo Bolt $\square$ Flowdrill Figure 12 Influence of the column flange thickness on the column flange bending resistance

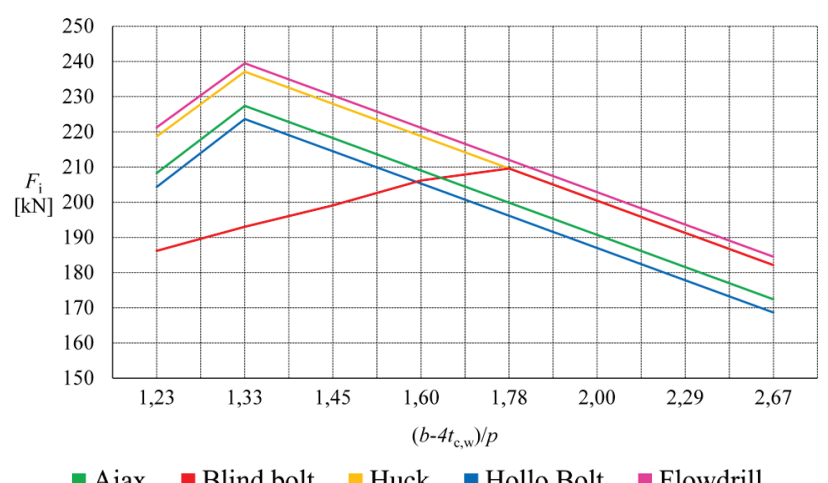

Ajax Blind bolt Huck Hollo Bolt Flowdrill

Figure 13 Column flange resistance $F_{i}$ in dependence on the ratio $\left(b-4 t_{\mathrm{c}, \mathrm{w}}\right) / p$

The length of RHS clear face and the bolt distance ratios, $\left(b-4 t_{\mathrm{c}, \mathrm{w}}\right) / p$ and $\left(b-4 t_{\mathrm{c}, \mathrm{w}}\right) / w$, represent the slenderness of the RHS clear face in two perpendicular directions. In all analysed cases, this ratio varied between $1,05 \div 3,6$.

The two ratios are observed in two examples where the following parameters are fixed: column yield strength $f_{\mathrm{y}, \mathrm{c}}=275 \mathrm{MPa}$, column flange wall thickness $t_{\mathrm{c}, \mathrm{w}}=10$ $\mathrm{mm}$, endplate thickness $t_{\mathrm{p}}=12 \mathrm{~mm}, \mathrm{M} 20$ bolt with quality grade 8.8 . In the first example (Tab. 4, Fig. 13), the vertical bolt distance varies between $p=60 \div 130 \mathrm{~mm}$, while the horizontal bolt distance remains the same, $w=$ $100 \mathrm{~mm}$. In the second example (Tab. 5, Fig. 14), the horizontal bolt distance varies between $w=60 \div 130 \mathrm{~mm}$, while the vertical bolt distance remains unchanged, $p=$ $100 \mathrm{~mm}$.

Tabs. 4 and 5 show joint failure modes; R4 represents column face in bending, while R7 represents endplate in bending failure. 
Table 4 Change in failure mode depending on the ratio $\left(b-4 t_{\mathrm{c}, \mathrm{w}}\right) / p$

\begin{tabular}{|c|c|c|c|c|c|}
\hline$\left(\frac{\left(b-4 \cdot t_{\mathrm{c}, \mathrm{w}}\right)}{2}\right.$ & \multicolumn{5}{|c|}{ Failure mode } \\
\cline { 2 - 6 } & Flowdrill & Hollo bolt & Huck & Blind bolt & $\begin{array}{c}\text { Ajax } \\
\text { ONESIDE }\end{array}$ \\
\hline 1,23 & $\mathrm{R} 7$ & $\mathrm{R} 7$ & $\mathrm{R} 7$ & $\mathrm{R} 7$ & $\mathrm{R} 7$ \\
\hline 1,33 & $\mathrm{R} 4$ & $\mathrm{R} 4$ & $\mathrm{R} 4$ & $\mathrm{R} 7$ & $\mathrm{R} 4$ \\
\hline 1,45 & $\mathrm{R} 4$ & $\mathrm{R} 4$ & $\mathrm{R} 4$ & $\mathrm{R} 7$ & $\mathrm{R} 4$ \\
\hline 1,60 & $\mathrm{R} 4$ & $\mathrm{R} 4$ & $\mathrm{R} 4$ & $\mathrm{R} 7$ & $\mathrm{R} 4$ \\
\hline 1,77 & $\mathrm{R} 4$ & $\mathrm{R} 4$ & $\mathrm{R} 4$ & $\mathrm{R} 4$ & $\mathrm{R} 4$ \\
\hline 2,00 & $\mathrm{R} 4$ & $\mathrm{R} 4$ & $\mathrm{R} 4$ & $\mathrm{R} 4$ & $\mathrm{R} 4$ \\
\hline 2,29 & $\mathrm{R} 4$ & $\mathrm{R} 4$ & $\mathrm{R} 4$ & $\mathrm{R} 4$ & $\mathrm{R} 4$ \\
\hline 2,67 & $\mathrm{R} 4$ & $\mathrm{R} 4$ & $\mathrm{R} 4$ & $\mathrm{R} 4$ & $\mathrm{R} 4$ \\
\hline
\end{tabular}

Legend: R4 column flange in bending failure, $\mathrm{R} 7$ endplate in bending failure.

Table 5 Change in failure mode depending on the ratio $\left(b-4 t_{\mathrm{c}, \mathrm{w}}\right) / w$

\begin{tabular}{|c|c|c|c|c|c|}
\hline \multirow{2}{*}{$\left(b-4 \cdot t_{\mathrm{c}, \mathrm{w}}\right)$} & \multicolumn{5}{|c|}{ Failure mode } \\
\cline { 2 - 6 } & Flowdrill & $\begin{array}{c}\text { Hollo } \\
\text { bolt }\end{array}$ & Huck & Blind bolt & $\begin{array}{c}\text { Ajax } \\
\text { ONESIDE }\end{array}$ \\
\hline 1,23 & $\mathrm{R} 7$ & $\mathrm{R} 7$ & $\mathrm{R} 7$ & $\mathrm{R} 7$ & $\mathrm{R} 7$ \\
\hline 1,33 & $\mathrm{R} 4$ & $\mathrm{R} 4$ & $\mathrm{R} 4$ & $\mathrm{R} 7$ & $\mathrm{R} 4$ \\
\hline 1,45 & $\mathrm{R} 4$ & $\mathrm{R} 4$ & $\mathrm{R} 4$ & $\mathrm{R} 7$ & $\mathrm{R} 4$ \\
\hline 1,60 & $\mathrm{R} 4$ & $\mathrm{R} 4$ & $\mathrm{R} 4$ & $\mathrm{R} 7$ & $\mathrm{R} 4$ \\
\hline 1,78 & $\mathrm{R} 4$ & $\mathrm{R} 4$ & $\mathrm{R} 4$ & $\mathrm{R} 4$ & $\mathrm{R} 4$ \\
\hline 2,00 & $\mathrm{R} 4$ & $\mathrm{R} 4$ & $\mathrm{R} 4$ & $\mathrm{R} 4$ & $\mathrm{R} 4$ \\
\hline 2,29 & $\mathrm{R} 4$ & $\mathrm{R} 4$ & $\mathrm{R} 4$ & $\mathrm{R} 4$ & $\mathrm{R} 4$ \\
\hline 2,67 & $\mathrm{R} 4$ & $\mathrm{R} 4$ & $\mathrm{R} 4$ & $\mathrm{R} 4$ & $\mathrm{R} 4$ \\
\hline
\end{tabular}

Legend: $\mathrm{R} 4$ column flange in bending failure, $\mathrm{R} 7$ endplate in bending failure.

The same examples are shown on diagrams in Fig. 13 and Fig. 14. The diagrams show influence of the RHS clear face and bolt distance ratio. Since the column flange thickness is lower than the endplate thickness in both of these examples, one would expect that the column flange fails sooner than the endplate. In spite of this, the examples prove that in the case of the lowest ratio $(1,23)$ the yield lines will actually form on the ticker endplate. When this happens, the bolts are placed on the edge of the RHS clear face. There is a large variety of factors that could influence this behaviour, and most important are position of the I section and curved corners of the section where increased level of support is provided. Further reduction of bolt distances, in both directions, will reduce the column flange bending resistance.

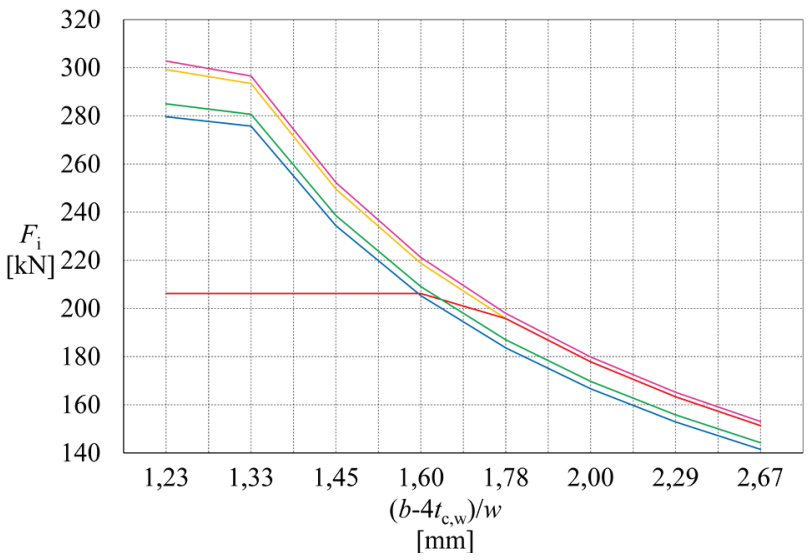

Ajax Blind bolt Huck Hollo Bolt $\square$ Flowdrill

Figure 14 Column flange resistance $F_{\mathrm{i}}$ in dependence on the ratio $\left(b-4 t_{\mathrm{c}, \mathrm{w}}\right) / w$

Park [6] analysed column flange failure modes. He noticed that a column flange can fail over a bolt group or a bolt row. The parametric analysis showed that bolt row failure can be expected at larger bolt distances, in both directions, when the ratio $\left(b-4 t_{\mathrm{c}, \mathrm{w}}\right) / p$ takes the minimal values between $1,05 \div 1,5$, [1]. With adopted column flange width $(b=200 \mathrm{~mm})$, the results have shown that bolt row failure will be govern if bolts are larger (M16 or M20), column flange is ticker $\left(t_{\mathrm{c}, \mathrm{w}}=12,5 \div 16 \mathrm{~mm}\right)$ and bolt distances in both directions are higher $(p=100 \div 130$ $\mathrm{mm}$ and $w=100 \div 130 \mathrm{~mm}$ ). Fig. 15 shows the change in a component's resistance when a bolt row failure occurs. The diagram's breaking point on $\left(b-4 t_{\mathrm{c}, \mathrm{w}}\right) / p=1,36$ occurs after the change of bolt distances in both directions. It can be concluded that this failure mode is specific in cases where bolt distances are high and the column flange has a high bending resistance.

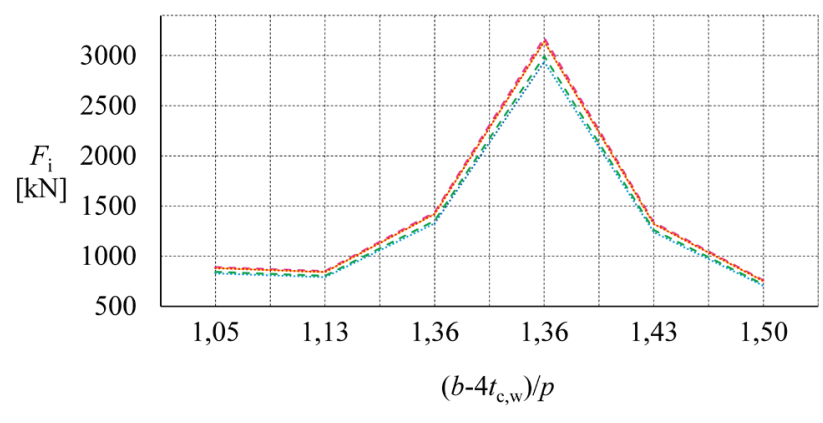

ajax $\square$ Blind bolt $\square$ Huck $\square$ Hollo Bolt $\square$ Flowdrill

Figure 15 Column flange resistance $F_{\mathrm{i}}$ in dependence on the ratio $\left(b-4 t_{\mathrm{c}, \mathrm{w}}\right) / p-$ bolt row failure

Naturally, by increasing the steel quality of column, its flange bending resistance is increased proportionally. A more detailed discussion of this issue can be found in $[1]$.

\section{Conclusion}

Conducted parametric analyses have shown certain rules in the behaviour of beam-to-column joints with an extended endplate and various blind bolt systems.

There are three typical failure modes which are critical when observing joints with an extended endplate and various blind bolt systems in cases where the column is a square tubular profile (RHS). The failure modes are as follows: bolt in tension, column flange in bending and endplate in bending. The most common failure mode of analysed type of joint was column face in bending. The percentage of the column face in bending failure in all of the analysed bolt systems varied between $53 \div 68 \%$. The difference in these results is due to Blind bolt system having the lowest tensile resistance and showing a higher ratio of bolt in tension failure when compared to other blind bolt systems (23\% when assuming the Blind bolt quality grade 8.8 ).

Bolt in tension failure is not a common failure mode. It occurs when smallest M12 bolts, as well as M16 bolts in Hollo-Bolt system, are used, Tab. 1. The total column flange and endplate thickness at which bolt in tension occurs varies between $24,5 \div 28,5 \mathrm{~mm}$ for M12 bolts. For M16 Hollo-Bolt system bolts minimum total thickness is $28 \mathrm{~mm}$. The Blind bolt system is, once again, an exception to this since it has a low tensile resistance of a bolt, [11]. Huck and Ajax ONESIDE have the highest bolt tensile resistance, $[12,13]$. Individual observations have shown that only joints using Blind bolt systems 
experience failure when column flange or endplate thickness is below $6 \mathrm{~mm}$. All other systems have experienced bolt failure at minimal column or endplate thickness of $12 \mathrm{~mm}$.

Failure of the endplate occurs when $t_{\mathrm{p}} / t_{\mathrm{c}, \mathrm{w}}<1,0$. This applies to pure yielding of the endplate as well as combined failure mode.

The bending resistance of the column flange depends on the bolthole size of each individual system. Therefore, systems that require a larger hole with the same nominal bolt diameter have a lower bending resistance. This applies to Hollo-Bolt and Ajax ONESIDE systems which require the largest boltholes for installation.

Column flange in bending through bolt row occurs in a smaller number of cases when bolt distance is higher, i.e. $\left(b-4 t_{\mathrm{c}, \mathrm{w}}\right) / p=1,05 \div 1,5$. Bolt group failure occurs when bolt distances are lower.

The assessment of the column flange bending resistance is more reliable when, instead of $b-t_{\mathrm{c}, \mathrm{w}}$ for the width of RHS clear face, the $b-4 t_{c, w}$ is used. Assessment with a lower width of RHS clear face implies a higher bending resistance value, which is in accordance with Park's findings, [6].

The linear yield line pattern gives minimal resistance values for lower bolt distances, while the circular yield line pattern is applicable for higher bolt distances. However, the elliptical yield line pattern gives minimal bending resistance values in all cases and its usage is recommended.

Due to membrane action effect, the bending resistance of the column flange increases. This is in close relation to the recent test results, [6], and thus it is recommended to take it into account during the assessment. If the current equation for column flange bending resistance would be replaced by the equation of simultaneous membrane action and yielding of the hollow section, the thread stripping failure in Flowdrill systems could become valid. Such a failure mode was seen often in laboratory tests $[6,11]$, which implies that current linear and circular yield line patterns underestimate the actual bending resistance of the column flange.

\section{References}

[1] Javora, A. Resistance of bolted joints with different blind bolt systems. / pre-Bologna master thesis, (mentor: Skejić, D.), Faculty of Civil Engineering, University of Zagreb, Zagreb, 2013. (in Croatian)

[2] Skejić, D. Reliability assessment of beam-to-column joints with cleats. / Dissertation, Faculty of Civil Engineering, University of Zagreb, Zagreb, 2009. (in Croatian).

[3] European Committee for Standardisation (CEN): EN 19931-8: Eurocode 3: Design of steel structures, Part 1-8: Design of joints. Brussels: CEN; 2005.

[4] Barnett, T.; Tizani, W.; Nethercot, D. The practice of blind bolting connections to structural hollow sections: a review. // Steel Composite Structures. 1, (2001), pp. 1-16. https://doi.org/10.12989/scs.2001.1.1.001

[5] Kurobane, Y.; Packer, J. A.; Wardenier, J.; Yeomans, N. Design Guide 9 for structural hollow section column connections. 1st ed. CIDECT, 2005.

[6] Park, A. Y. Semi-rigid joints to tubular columns and their use in semi-continuous frame design. / Ph.D. thesis, Faculty of Engineering and Physical Sciences, University of Manchester, Manchester, UK, 2012.
[7] British Steel. (1996b). CIDECT Report No. 6F-13B/96 Flowdrill Jointing System Part 2 Structural Hollow Section Connections. Corby, England: British Steel Tubes \& Pipes

[8] British Steel. (1996). CIDECT Report No. 6G-14(A)/96 TS\&MD Report No. P034.S.06-1/96: Hollofast and Hollobolt System for Hollow Section Connections, Corby, England: British Steel Tubes \& Pipes.

[9] Mourad, S. Behaviour of blind bolted moment connections for square HSS columns. / Ph.D. thesis. Canada McMaster University, 1994

[10] Korol, R. M.; Mitri, H.; Mirza, F. A. Plate reinforced square hollow section T-joints of unequal width. // Canadian Journal of Civil Engineering. 9, 2(1982), pp. 143148. https://doi.org/10.1139//82-017

[11] Blind Bolt Company, Thin Wall Bolt product specification, URL: www.blindbolt.co.uk, (20.06.2013)

[12] Huck Fastening Systems, URL: www.fsrivet.com, (20.06.2013)

[13] Fernando, S. Joint design using ONESIDE TM structural fastener. // Technical note: AFI/03/012, Ajax Fasteners, Victoria, 2005.

\section{Authors' addresses}

Anka Javora, univ. spec. aedif

Ministry of Construction and Physical Planning

Ulica Republike Austrije 20, 10000 Zagreb, Croatia

E-mail: anka.javora@mgipu.hr

Davor Skejić, PhD

University of Zagreb

Faculty of Civil Engineering, Department for Structures

Fra Andrije Kacica-Miosica 26, 10000 Zagreb, Croatia

E-mail: davors@grad.hr 